\title{
Evaluation for User's Satisfaction on Pathway and Street Furniture Facilities in Thamrin-Sudirman Area
}

\author{
Yaseri Dahlia Apritasari ${ }^{1}$ \\ ${ }^{1}$ Architecture Program, Podomoro University, Indonesia \\ yaseri.apritasari@podomorouniversity
}

\begin{abstract}
The Global Climate Change Problem is a global problem throughout the world. This requires the attention of all countries to commit to reducing carbon footprint by reducing the use of private vehicles one way of their lives. So, the development of cities when they need to be designed using a carbon footprint. Design cities to encourage people to use public transportation and motivate people to walk. The Thamrin and Sudirman Areas are trade and service centers, primary activity centers, and a strategic area (Integrated Commerce Center and Dukuh Atas area are exchanges of mass public transport (TOD)). As a provincial strategic area, for the past five years, the DKI Provincial government has built pedestrian and public transportation facilities to improve the convenience of pedestrian and public transportation users. This study discusses road user satisfaction with pedestrian facility requirements: Lanes, road furniture, and nameplates in the Thamrin Sudirman area. This study examines user satisfaction in pedestrian facilities in the Thamrin Sudirman area. Locations in Thamrin Sudirman: Sarinah, Bunderan Hotel Indonesia, Dukuh Atas, Setia Budi-Chase Plaza, Bendungan Hilir-Atmajaya, Gelora Bung Karno, Sudirman-MRT Senayan-Ratu Plaza, and ASEAN MRT area. Survey assessment tools based on satisfaction levels of 1-9 scale, with criteria for elements: (1) Path (Property, design, quality, hallway, shade, lighting, user-friendliness, landscaping, maintenance, environment), (2) Street furniture and signage (Furniture and road shades, lamp post-placement, information boards, signage). The results showed the Sudirman-MRT Senayan-Ratu Plaza area and the Gelora Bung Karno area, as a road that was considered to have a high level of satisfaction for pedestrians. Pathway design, street furniture, and signage can fulfill pedestrian satisfaction. Thus, it is expected that the design of pedestrian paths in these locations can be a reference for the design of pedestrian facilities.
\end{abstract}

(c) 2020 IJBESR. All rights reserved.

Keywords: Satisfaction, users, pathways, street furniture

\section{Introduction}

Global climate change is a world problem, and it is the responsibility of all countries and all people to change lifestyles. It aims to reduce the carbon footprint. Now, city planning has moved towards using a green approach - the green city planning with increasing green area, improving public transportation facilities and pedestrian path facilities. Open green space and pedestrian path area can be designed with the proportion of vegetation consisting: grass, bushes, and trees. This strategy can reduce urban heat island, produce $\mathrm{O} 2$, and reduce $\mathrm{CO} 2$.
The City Government of Jakarta has been implementing green city planning. One of the planned areas is the Thamrin-Sudirman area. The area is a trade and regional center area, as well as a primary activity center, and is a provincial strategic area (Integrated Commerce Center and Dukuh Atas area is an exchange of mass public transport (TOD)) [6]. The Thamrin-Sudirman area is currently a highdensity office, trade, and service area on weekdays (Monday-Friday). Specific problems are traffic congestion, and the carrying capacity of road facilities does not support the volume of private vehicles. Government has various 
strategies and regulation to reduce congestion at these locations, namely:

1. Three-in-one regulations in the Thamrin and Sudirman area, which are enforced in the morning between 07.00 and 10.00 and in the evening between 17.30-19.00

2. Trans Jakarta construction on the KotaBlok $M$ route, the route passes Thamrin Sudirman area

3. Regulation of odd and even vehicle numbers arrangement at Thamrin Sudirman area [5]

However, this policy has not been able to solve the problem of carbon reduction in the Thamrin Sudirman area. The Government of Jakarta Province continues to develop policies on how to reduce the carbon footprint. For five years, it has been developing strategies to improve public transportation infrastructure facilities:

1. Public transportation facilities: Bus stops, waiting rooms, information boards, access. Cross-bridge facilities, mass-rapid transportation (MRT), shade, and shelter.

2. Pedestrian way facilities: Pathways (property, design, quality, hallway, shade, lighting, user-friendliness, landscaping, maintenance, and environment), and street furniture and signage (furniture and road shading, placement of light poles, information boards, information boards, signage).

Improving public transportation and pedestrian way facilities motivate and encourage more people to walk and ride public transportation. This research aims to discuss the satisfaction of pedestrian path facilities: Pathway, street furniture, and signage in the Thamrin Sudirman area. Research methodology through qualitative and quantitative methods for the level of pedestrian way user's satisfaction.

This paper is divided into four sections, the first section is an introduction, the second section will discuss the background, literature review about pedestrians, pedestrian way facilities that increase pedestrian satisfaction, and, impact for decrease carbon displacement, and methodology research. Then the third section is the result and discussion, and the fourth section is the conclusion.

\section{Material and Methods}

Walking is the cheapest, healthiest, and most universal mode of transportation that anyone can do [18]. Walking is also a simple exercise, it can minimize the carbon footprint, and low cost, then everyone can do it: Young people, senior citizens, young children, and the disabled [7]. Therefore, pedestrian path infrastructure and environment must be provided to encourage people to walk. The pedestrian path concept has a significant role, that is, to consider the physical condition of the pedestrian path [14]. Physical conditions of pedestrian paths include the quality of pedestrian path and features, environment quality, safety, traffic speed, and flow, thus satisfaction. Environmental conditions for pedestrian paths are spaces for social interaction along pedestrian paths as well as arts, and cultural activities are located in a tourist area $[10,12]$. The dynamics and speed of pedestrians are higher in office and commercial regions than in residential and recreational areas [8]. But this also depends on the pedestrian path's width, the type of facility, and environmental factors surrounding the pedestrian path [3]. The correlation between pedestrian activity and satisfaction versus infrastructure and pedestrian path facilities is significant.

Pedestrian's satisfaction depends on physically enticing environments. It has full pedestrian facilities such as sidewalks or paths, marked pedestrian crossings, appropriate lighting and street furniture, useful, signage, and street trees. They may also include interesting architecture, 
pleasant views, and abundant services attractive to those who have other choices for getting around and getting exercise [21].

The research will evaluate the condition of pedestrian satisfaction toward the pedestrian path in the Thamrin-Sudirman area. This area is a primary activity center area (offices and commercial) with high mobility and activities in a very dense area (Spatial Planning for DKI Jakarta Province for 2010-2030). This high mobility should be accompanied by high motivation to walk from one activity to another in one region. In supporting pedestrian motivation by increasing pedestrian facilities, it is necessary to measure pedestrian's satisfaction.

Studies on the level of pedestrian satisfaction have been carried out by various methods [1, 11]. One of the measurement methods is walkable path capacity and road condition characteristics [4, 19]. Another satisfaction method is using an assessment of perception based on the pedestrian's infrastructure and attributes [13]. This measurement methodology includes quantitative and qualitative [9]. The satisfaction scale could be measured based on perceptions measured with satisfaction scale and condition of the design of pedestrian path infrastructure.

\section{Methodology}

This research methodology uses qualitative and quantitative approaches. Research stages divided:

- The first, observing and identifying pathway, street furniture, and signage on Thamrin and Sudirman areas.

- The second, assessing pedestrian's satisfaction toward pathway, street furniture, and signage attribute condition.

- The third: Evaluating the relationship between pedestrian's satisfaction and the design of pedestrian facilities.
- The fourth: Giving recommendation for convenient pedestrian path design: Pathway, street furniture and signage that optimally motivates and satisfies pedestrians.

The first stage is observation and identification of the physical condition of the pathway and street furniture and pedestrian signage in the Thamrin Sudirman area. Details of the observed elements can be seen in Table 1 .

Table 1 Detailed element pathway, street furniture and signage

\begin{tabular}{|c|c|}
\hline Elements & Details \\
\hline Pathway & $\begin{array}{l}\text { Properties, design, quality, } \\
\text { alleys, shade, lighting, user } \\
\text { friendly, landscaping, } \\
\text { maintenance, environment. }\end{array}$ \\
\hline $\begin{array}{l}\text { Street furniture } \\
\text { and signage }\end{array}$ & $\begin{array}{l}\text { Street furniture and shade, } \\
\text { placement of lamp post, } \\
\text { board information, signage }\end{array}$ \\
\hline
\end{tabular}

Source: (Zainol, et al., 2014) [16]

For the second, this study uses a questionnaire approach to collect its primary data. A total of 42 respondents are age 18-23 years old. They walked in each area and then gave satisfaction ratings.

The evaluation was based on a 1-9 Likert rating scale, with one very unsatisfied, and nine being very satisfied. The results of this assessment will show the trend and consistency of the scale of the nine points Saaty [17]. The scale is used to determine the value of pedestrian satisfaction with the condition of pathway elements, street furniture, and signage. Evaluation of the assessment of pedestrian satisfaction scale will be combined with element pathway facilities, street furniture, and signage, which then made recommendations for convenient pedestrian facilities. Table 2 shows the details of the User's Satisfaction Value.

The study took place in Thamrin Sudirman 
Area; the area is a trade and regional center area and a primary activity center. And it is a provincial strategic area (Integrated Commerce Center and Dukuh Atas area is an exchange of mass public transport (TOD)) [6]. The Pedestrian walkways that were evaluated are the Thamrin Sudirman corridor, which covers eight areas: Sarinah area, Bunderan Hotel Indonesia area, Dukuh Atas area, Setiabudi-Chase Plaza area, Bendungan Hilir - Universitas Atmajaya area, Gelora Bung Karno (GBK) area, Sudirman MRT Senayan- Ratu Plaza area, dan MRT ASEAN area. The eight locations observed have easy and close access to public transportation: MRT and Trans Jakarta (Figure 1).

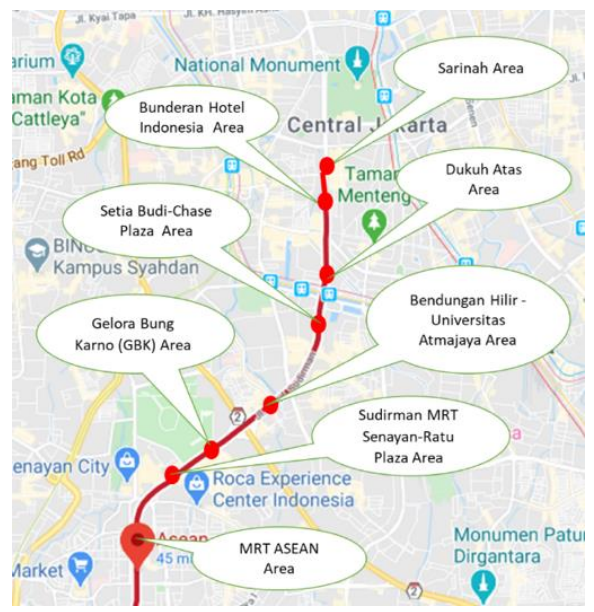

Figure 1: Map of selected pedestrian path on ThamrinSudirman Area

Source: (Google, edited by author, 2020)

Table 2: User's satisfaction value

\begin{tabular}{|c|c|c|c|}
\hline \multirow{2}{*}{\multicolumn{2}{|c|}{ Location }} & \multicolumn{2}{|c|}{ User's Satisfaction Value } \\
\hline & & $\begin{array}{l}\text { Pathway } \\
\text { Elements }\end{array}$ & $\begin{array}{c}\text { Street } \\
\text { furniture and } \\
\text { signage } \\
\text { Elements }\end{array}$ \\
\hline A. & Sarinah Area & $1-10$ & $1-10$ \\
\hline B. & $\begin{array}{l}\text { Bunderan Hotel } \\
\text { Indonesia Area }\end{array}$ & $1-10$ & $1-10$ \\
\hline C. & Dukuh Atas Area & $1-10$ & $1-10$ \\
\hline D. & $\begin{array}{l}\text { Setiabudi-Chase } \\
\text { Plaza Area }\end{array}$ & $1-10$ & $1-10$ \\
\hline E. & $\begin{array}{l}\text { Bendungan Hilir - } \\
\text { Universitas } \\
\text { Atmajaya Area }\end{array}$ & $1-10$ & $1-10$ \\
\hline
\end{tabular}

\begin{tabular}{llll}
\hline F. & $\begin{array}{l}\text { Gelora Bung Karno } \\
\text { (GBK) Area }\end{array}$ & $1-10$ & $1-10$ \\
G. & $\begin{array}{l}\text { Sudirman } \\
\text { Senayan- MRT }\end{array} \quad 1-10$ & $1-10$ \\
& $\begin{array}{l}\text { Plaza Area } \\
\text { H. Ratu }\end{array}$ & & \\
MRT ASEAN Area & $1-10$ & $1-10$ \\
\hline
\end{tabular}

Source: (Author, 2020)

Every pedestrian path has different pathway elements, street furniture, and signage-the condition of facility pathway elements data based on maps and field observations. The pedestrian's satisfaction perception questionnaire will be compared to every areacomparison based on mean, modus, and a significant index value of user's satisfaction. The result will show the highest user satisfaction value toward pathway, and street furniture and signage condition. The final result will be a recommendation for the design of convenient pathway elements, street furniture, and signage.

Description pedestrian path area:

1. Sarinah Area

\section{Pathway}

The 4-6-meter walkway is provided for two ways of pedestrian flow. The pedestrian way material is a natural stone and paving block. Some streetlights are bright enough. Providing a park (bush \& small tree) 0.5-1-meter wide as a barrier to the road. Pedestrian material and design are easy to maintain.

\section{Street furniture and signage}

There is a signage of pedestrian paths and bicycle paths. Available benches with wood and iron material, then shade from the shadow of the tree. The lighting from the streetlamps is designed in such a way and quite good quality. There is a 1-meter high concrete pole, on the intersection of pedestrian paths and road vehicles. It protects pedestrians from vehicles. Then for disabled users, there is a 
guiding block (blind pattern) and a ramp.

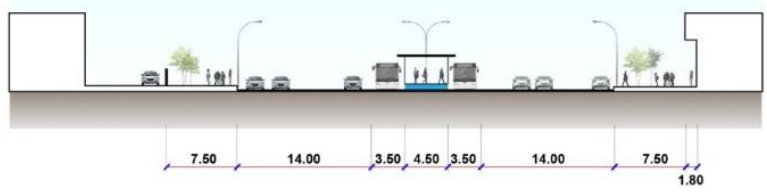

Figure 2: Pedestrian path and road section on Sarinah area

Source: (Author, 2020)

1. Bunderan Hotel Indonesia Area.

\section{Pathway}

The 6-8-meter walkway is provided for two ways of pedestrian flow. The pedestrian way material is a natural stone and paving block. Some streetlights are bright enough.

For separator between the road and walkable vehicles used a park (bush \& small tree) 0.5-1-meter wide. Pedestrian material and design are easy to maintain.

\section{Street furniture and signage}

There is a signage of pedestrian paths and bicycle paths. Available benches with wood and iron material, then shade from the shadow of the tree. The lighting from the streetlamps is designed in such a way and quite good quality. There is a 1-meter high concrete pole, on the intersection of pedestrian paths and road vehicles. It protects pedestrians from vehicles. Then for the disabled users, there is a guiding block (blind pattern) and a ramp.

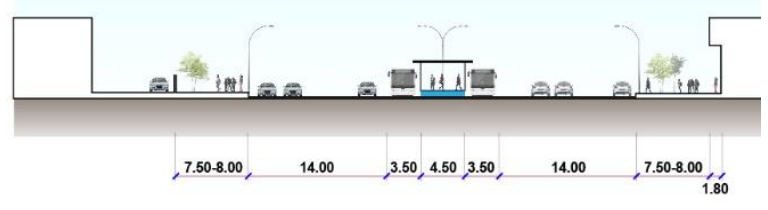

Figure 3: Pedestrian path and road section on Bunderan Hotel Indonesia Area area
Source: (Author, 2020)

2. Dukuh Atas Area

\section{Pathway}

The 4-6-meter walkway is provided for two ways of pedestrian flow. The pedestrian way material is a paving block. Some streetlights are bright enough. For separator between the road and walkable vehicles used a park (bush \& small tree) 1-2-meter-wide. Pedestrian material and design are easy to maintain.

\section{Street furniture and signage}

There is a signage of pedestrian paths and information for the schedule of public transportation. The lighting from the streetlamps is designed in such a way and quite good quality. Then for the disabled users, there is a guiding block (blind pattern) and a ramp.

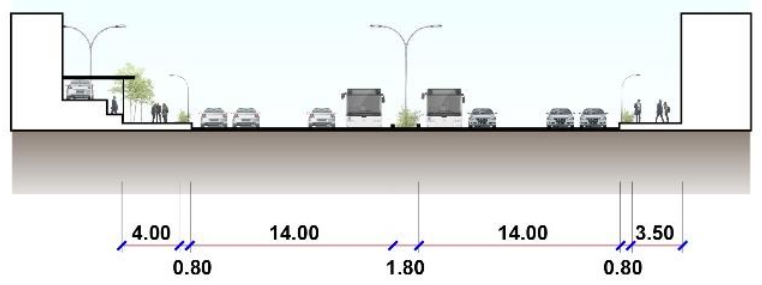

Figure 4: Pedestrian path and road section on Dukuh Atas area Source: (Author, 2020)

3. Setiabudi-Chase Plaza Area.

\section{Pathway}

The 8-10-meter walkway is provided for two ways of pedestrian flow. The pedestrian way material is paving blocks. Some streetlights are bright enough. For separator between the road and walkable vehicles used a park (bush \& small tree) 1.2-2-meter wide. Pedestrian material and design are easy to maintain.

Street furniture and signage 
There is a signage of pedestrian paths and bicycle paths. Available benches with wood and iron material, then shade from the shadow of the tree. The lighting from the streetlamps is designed in such a way and quite good quality. There is a 1-meter high concrete pole, on the intersection of pedestrian paths and road vehicles. It protects pedestrians from vehicles. Then for the disabled users, there is a guiding block (blind pattern) and a ramp.

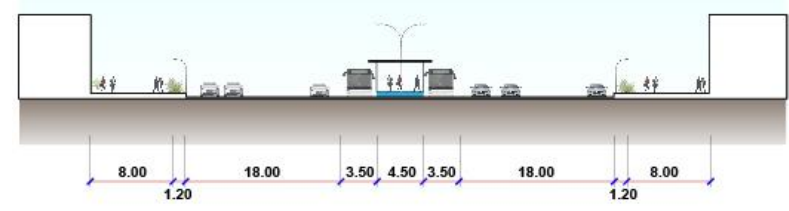

Figure 5: Pedestrian path and road section on Setiabudi-Chase Plaza Area Source: (Author, 2020)

4. Bendungan Hilir - Universitas Atmajaya Area.

\section{Pathway}

The 6-8-meter walkway is provided for two ways of pedestrian flow. The pedestrian way material is paving blocks. Some streetlights are bright enough. For separators between the road and walkable vehicles used a park (bush \& small tree) 4-meter wide. Pedestrian material and design are easy to maintain.

\section{Street furniture and signage}

There is a signage of pedestrian paths and bicycle paths. Available benches with natural stone material, then shade from the shadow of the tree. The lighting from the streetlamps is designed in such a way and quite good quality. There is a 1-meter high concrete pole, on the intersection of pedestrian paths and road vehicles. It protects pedestrians from vehicles. Then for the disabled users, there is a striking yellow guiding block (blind pattern) and a ramp.

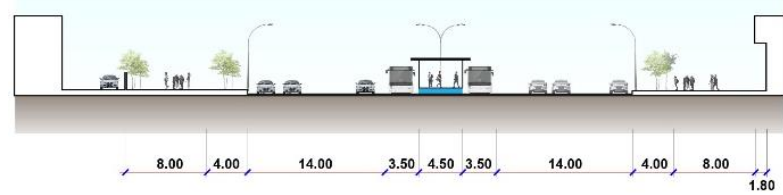

Figure 6: Pedestrian path and road section on Bendungan Hilir-Universitas Atmajaya Area. Source: (Author, 2020)

5. Gelora Bung Karno (GBK) Area.

\section{Pathway}

The 8-10-meter walkway is provided for two ways of pedestrian flow. Pedestrian way material concrete and natural stone. Some streetlights are bright enough. For separators between the road and walkable vehicles used a park (bush \& small tree) 4-meter wide. Pedestrian material and design are easy to maintain.

\section{Street furniture and signage}

There is the signage of pedestrian paths, bicycle paths, and information boards for public transport timetables. There is a bench with natural stone material, and shade is formed from the shade of vegetation and shelter. Lighting at night has been shown by street and garden lights designed in such a way and good enough quality. There is a 1-meter high concrete pole, on the intersection of pedestrian paths and road vehicles. It protects pedestrians from vehicles. Whereas for the disabled, there is a striking yellow guiding block (blind pattern) and ramp.

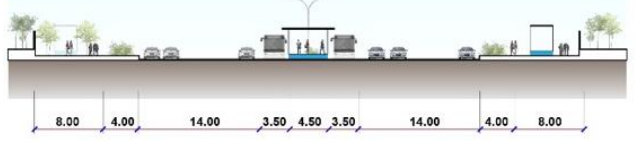


Figure 7: Pedestrian path and road section on Gelora Bung Karno (GBK) Area. Source: (Author, 2020)

6. Sudirman MRT Senayan- Ratu Plaza Area Pathway

The 7-8-meter walkway is provided for two ways of pedestrian flow. The pedestrian way material is: paving and natural stone. Some streetlights are bright enough. For separators between the road and walkable vehicles used a park (bush \& small tree) 4-meter wide. Pedestrian material and design are easy to maintain.

\section{Street furniture and signage}

There is the signage of pedestrian paths, bicycle paths, and information boards for public transport timetables. There is a bench with natural stone material, and shade from the shadow of vegetation and shelter. Lighting at night has been shown by street and garden lights that are designed in such a way and good enough quality. There is a 1-meter high concrete pole, on the intersection of pedestrian paths and road vehicles. It protects pedestrians from vehicles. Whereas for the disabled, there is a striking yellow guiding block (blind pattern) and ramp.

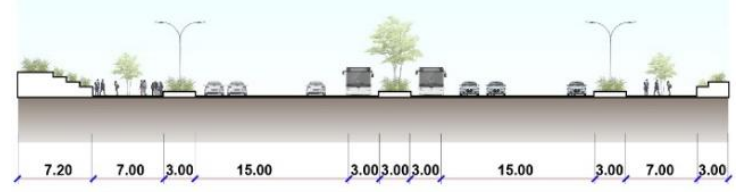

Figure 8: Pedestrian path and road section on Sudirman MRT Senayan-Ratu Plaza Area Source: (Author, 2020)

7. MRT ASEAN Area

Pathway

The 1.8-2.5-meter walkway is provided for two ways of pedestrian flow. The pedestrian way material is a paving block. There is a separator between the vehicle road and the pedestrian path with different heights. The boundary is in the form of a curb, thus another separator using iron pipe fences. Some pedestrian paths collide with trees and vegetation. There are streetlights and less lighting.

\section{Street furniture and signage}

The signage is only traffic signs. There is no shade and shelter-the lighting at night from streetlamp with low light quality. There are boundary poles to protect pedestrians at the intersection of pedestrian paths and road vehicles. Whereas for the disabled, there is a striking yellow guiding block (blind pattern), colliding with vegetation.

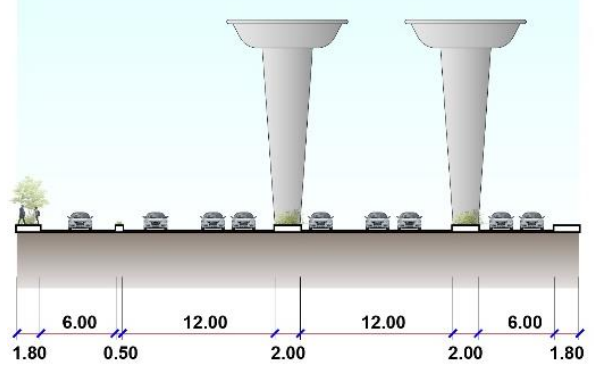

Figure 9: Pedestrian path and road section on MRT ASEAN Area

Source: (Author, 2020)

\section{Results and Discussions}

The first analysis phase is analyzing pedestrian's satisfaction value data toward pathways, and, street furniture and signatures. Analysis has been done by calculating the average pedestrian's satisfaction value and calculating the significant index value of the pedestrian's satisfaction value. This analysis looks at the tendency of pedestrian's satisfaction value to the design of pedestrian paths. The pedestrian satisfaction scale survey's results showed the Sudirman area of the MRT Senayan-Ratu Plaza Area has the highest average and significant index values for 
pathways, the value: 7.95 and 88.36 , and also for the highest average and significant index of street furniture and signage, namely: 7.86 and 87.30. For the Pathway sequence, the second Gelora Bung Karno area: 7.88, 87.57, then Bendungan Hilir-Atmajaya Area: 7.76, 86.24, Bunderan Hotel Indonesia Area: 7.69, 85.45, Sarinah Area: 7.31, 81.22, Setiabudi-Chase Plaza Area: 7.76, 86.24, Dukuh Atas Area: 6.88, 76.46, and then finally MRT ASEAN Area: 5.21, 57.94. Detailed satisfaction scale values can be seen in Table 3 .

Whereas for street furniture and signage the order is: The second Bundaran Hotel Indonesia Area: 7.48, 83.07, then Dukuh Atas Area: 7.43, 82.54, Gelora Bung Karno (GBK) Area: 7.36, 81.75, Bendungan Hilir-Universitas Atmajaya Area: 7.43, 80.42, Setiabudi-Chase Plaza Area: 7.24, 80.42, Sarinah Area: 6.95, 77.25, and finally MRT ASEAN Area: 5.45, 60.58. The detail satisfaction scale values can be seen in Table 4. These results can reflect the condition of the pedestrian facilities provided along this road.

Table 3: Values of pedestrian's satisfaction toward Sarinah area-MRT ASEAN Area Pathway.

\begin{tabular}{|c|c|c|c|c|}
\hline \multicolumn{5}{|c|}{ Pathway } \\
\hline & Area & Mean & Modus & $\begin{array}{l}\text { Significant } \\
\text { Index }\end{array}$ \\
\hline A. & Sarinah Area & 7.31 & 7.00 & 81.22 \\
\hline B. & $\begin{array}{l}\text { Bunderan Hotel } \\
\text { Indonesia Area }\end{array}$ & 7.69 & 7.00 & 85.45 \\
\hline C. & Dukuh Atas Area & 6.88 & 8.00 & 76.46 \\
\hline D. & $\begin{array}{l}\text { Setiabudi-Chase } \\
\text { Plaza Area }\end{array}$ & 7.26 & 8.00 & 80.69 \\
\hline E. & $\begin{array}{l}\text { Bendungan Hilir - } \\
\text { Universitas } \\
\text { Atmajaya Area }\end{array}$ & 7.76 & 8.00 & 86.24 \\
\hline F. & $\begin{array}{l}\text { Gelora Bung Karno } \\
\text { (GBK) Area }\end{array}$ & 7.88 & 8.00 & 87.57 \\
\hline G. & $\begin{array}{lr}\text { Sudirman } & \text { MRT } \\
\text { Senayan- } & \text { Ratu } \\
\text { Plaza Area } & \end{array}$ & 7.95 & 8.00 & 88.36 \\
\hline H. & $\begin{array}{l}\text { MRT ASEAN } \\
\text { Area }\end{array}$ & 5.21 & 6.00 & 57.94 \\
\hline
\end{tabular}

Source: (Author, 2020)

Table 4: Values of pedestrian's satisfaction toward
Sarinah area-MRT ASEAN Area Street furniture and signage

\begin{tabular}{|c|c|c|c|c|}
\hline \multicolumn{5}{|c|}{$\begin{array}{l}\text { Street furniture } \\
\text { and signage }\end{array}$} \\
\hline & Area & Mean & Modus & $\begin{array}{l}\text { Significant } \\
\text { Index }\end{array}$ \\
\hline A. & Sarinah Area & 6.95 & 8.00 & 77.25 \\
\hline B. & $\begin{array}{l}\text { Bunderan Hotel } \\
\text { Indonesia Area }\end{array}$ & 7.48 & 8.00 & 83.07 \\
\hline C. & $\begin{array}{l}\text { Dukuh Atas } \\
\text { Area }\end{array}$ & 7.43 & 8.00 & 82.54 \\
\hline D. & $\begin{array}{l}\text { Setiabudi-Chase } \\
\text { Plaza Area }\end{array}$ & 7.24 & 8.00 & 80.42 \\
\hline E. & $\begin{array}{l}\text { Bendungan Hilir } \\
-\quad \text { Universitas } \\
\text { Atmajaya Area }\end{array}$ & 7.43 & 8.00 & 80.42 \\
\hline F. & $\begin{array}{l}\text { Gelora } \quad \text { Bung } \\
\text { Karno } \\
\text { Area }\end{array}$ & 7.36 & 7.00 & 81.75 \\
\hline G. & $\begin{array}{lr}\text { Sudirman } & \text { MRT } \\
\text { Senayan- } & \text { Ratu } \\
\text { Plaza Area } & \end{array}$ & 7.86 & 8.00 & 87.30 \\
\hline H. & $\begin{array}{l}\text { MRT ASEAN } \\
\text { Area }\end{array}$ & 5.45 & 6.00 & 60.58 \\
\hline
\end{tabular}

Source: (Author, 2020)

The pedestrian's satisfaction survey results showed the highest pedestrian satisfaction value on the Sudirman MRT Senayan-Ratu Plaza Area. The area has attributes such as Pathway, street furniture, and signage, which can provide pedestrians' satisfaction. This pedestrian path has a width size: 7-8-meter; it can be freely traversed 5-6 people, comfortable and freely moving at different speeds each pedestrian. Other elements that make it comfortable are pedestrian path material: natural stone and outdoor ceramic, with flat degree pedestrian pathways. This pedestrian path condition gave pedestrians feel comfortable, not tired, and minimize foot injuries due to tripping. The precise boundaries between vehicle lanes and pedestrian paths have been shown by the existence of green lines or parks with bushes, shrub vegetation, and small tree such a Hymenocalis littoralis, Cordyline fruticosa fireland, Clorophytum comosum, boksus, asoka, nuts bushes, Saraca indica, and Japanese frangipani trees. It not only provided view satisfaction and shade but also gave felling a sense of security. Lighting in 
the area of the pedestrian path has been supplied from the streetlights, and also from the park. Both lights are designed in such a way that they not only fulfill lighting but also fulfill aesthetics.

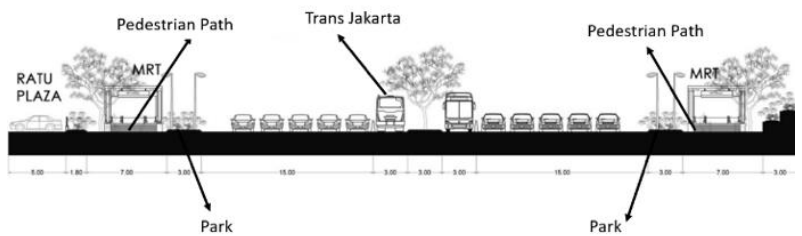

Figure 10: Detail of Pedestrian path and road section on MRT Sudirman-Ratu Plaza Source: (Author, 2020)

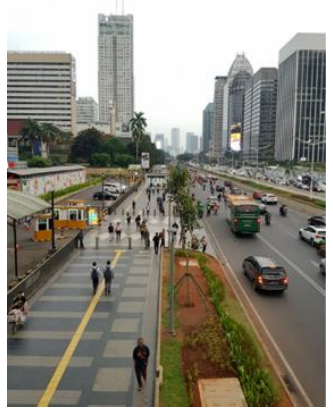

Figure 11: Pedestrian path condition, has 7-8-meter wide, natural stone material, yellow blind pattern for disabled users, and park as separated between pedestrian path and vehicle road. Source: (Author, 2020)

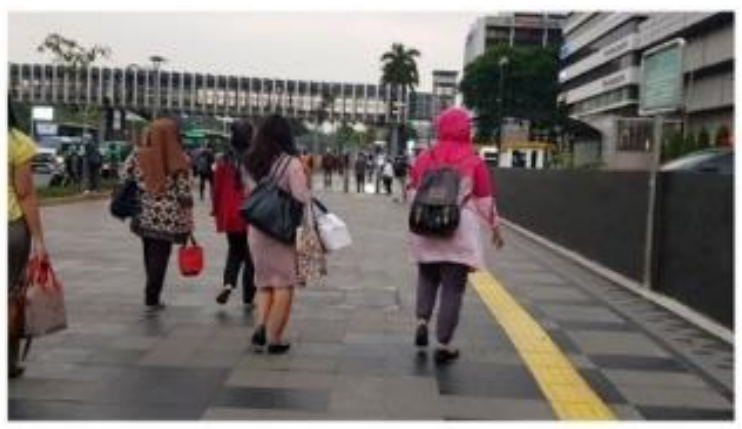

Figure 12: Pedestrian path condition, has 7-8-meter wide, natural stone material, yellow blind pattern for disabled users
Source: (Author, 2020)
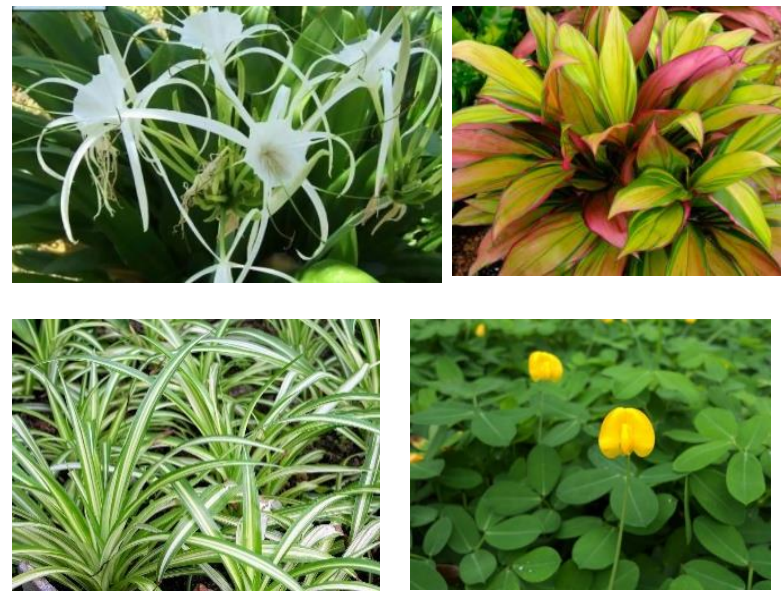

Figure 13: Clorophytum comosum and nuts bush, for park on pesestrian path environment. Source: (Author, 2020)
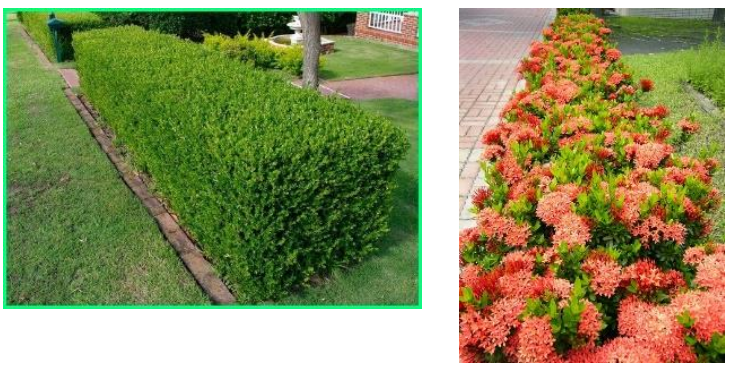

Figure 14: Boksu and Polyalthia longifolia, the vegetation for park on pesestrian path environment. Source: (Author, 2020)

There is also a bicycle path, which becomes one with the pedestrian path but is given clear signage. Thus, minimizing collisions between pedestrian and cycles. Intersection between pedestrian paths and road vehicles used different heights and connected by a ramp. It is facility that makes it easy for disabled users, children and parents. This intersection meeting is also given an iron pole or column as high as 0.8-1-meter which serves as a protective pedestrian from the vehicle. 


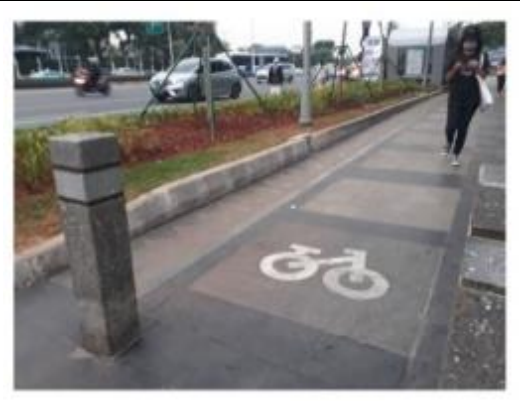

Figure 15: Provided bicycle path Source: (Author, 2020)

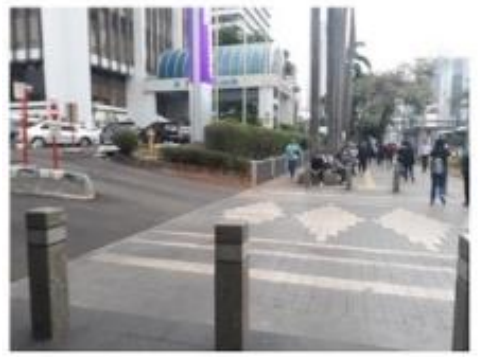

Figure 16: Provided concrete pole with 1-meter height to protect pedestrian from vehicle Source: (Author, 2020)

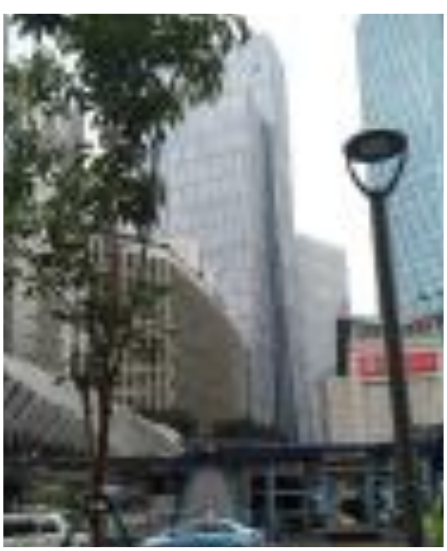

Figure 17: Street lamp is good enough lighting quality

Source: (Author, 2020)

Street furniture and signage available provide excellent satisfaction to pedestrians. Clear signage shows a clear separation between pedestrian paths and cyclist paths and signage on public transportation timetables at regular bus stops and Trans Jakarta. The signage guiding block (blind pattern) is designed to be striking yellow along the pedestrian path. The attributes of pedestrian shade are vegetation shade and shelter. Trees are arranged in such a way in pedestrian paths so that their roots and twigs do not disturb pedestrians. Then, for a resting place, an available static bench made of concrete with natural stone cover material, the color is designed to adjust the brightness of the pedestrian path's material. Other street furniture facilities are separated trust bin, divided organic, inorganic, and toxic acid waste.

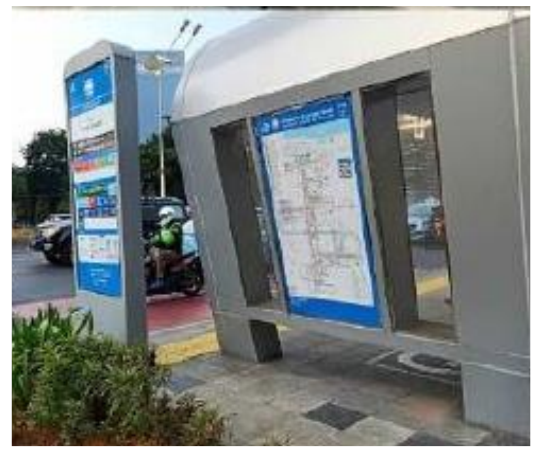

Figure 18: Signage on public transportation timetables at regular bus and Trans Jakarta stops Source: (Author, 2020)

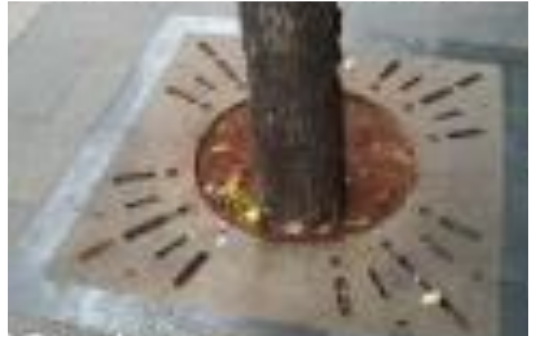

Figure 19: Detail of tree on the pedestrian path Source: (Author, 2020)
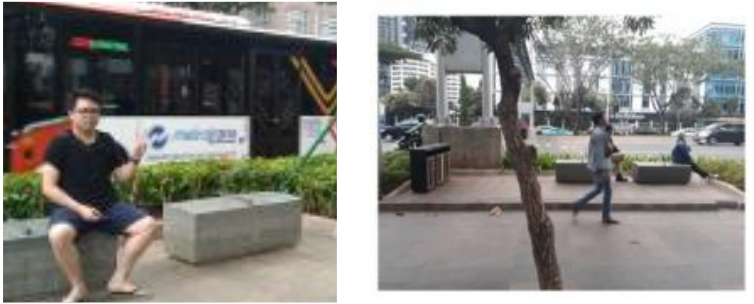

Figure 20: Shade and shelter on pedestrian path, there are bench from natural stone material and tree's shadow Source: (Author, 2020) 


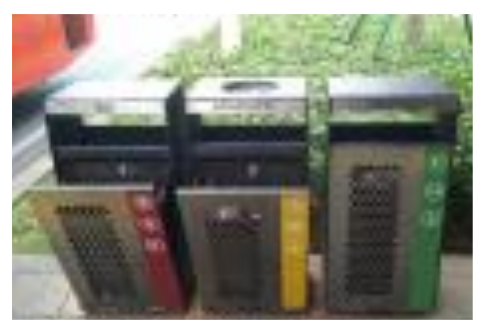

Figure 21: Separated trash bin: Organic, inorganic and toxic acid waste Source: (Author, 2020)

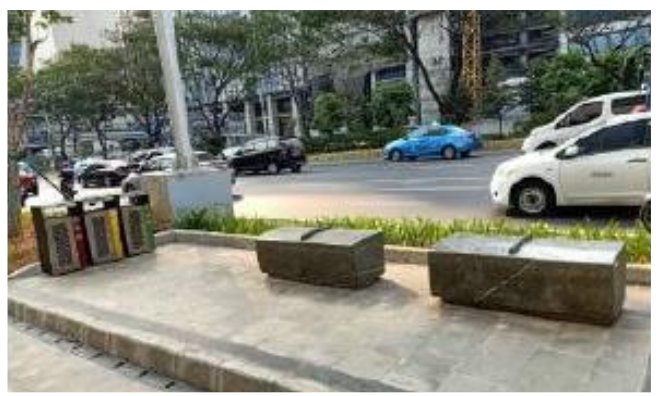

Figure 22: Design of rest area with bench made of stone material and available trash can in the pedestrian path environment Source: (Author, 2020)

The pedestrian pathway's design elements showed that the excellent design of pathways, street furniture, and signage design gives high pedestrian satisfaction. Pathways with wide pedestrian paths provide flexibility for pedestrians. Pedestrians comfortably walk uninterrupted from one another because of differences in pedestrian's speed of walking, walking alone, or in the group. Also, good street furniture and signage design and the right material will provide pedestrian comfort and satisfaction.

\section{Conclusion}

The research results showed that an indication of the criteria for pathway infrastructure, street furniture, and proper signage is needed to meet pedestrian satisfaction needs. The pedestrian paths in the Thamrin-Sudirman road corridor area are designed in such a way that is of the same standard for office and commercial areas. Still, because each area has a different character and land, different pathways, street furniture, and signage designs occur. This gives a different design and provides a different level of satisfaction. From the pedestrian satisfaction survey results, the design of the pedestrian pathway can be recommended:

1. Design the width of the pedestrian path that is free and comfortable for walking, namely: 6-10 meters.

2. To select material of pedestrian path robust and non-slippery surface, and no holes. For example, outdoor ceramics and natural stone.

3. To design a clear separation between the vehicle road and the pedestrian path that is safe and pay attention to aesthetics, for example, parks and vegetation.

4. To provide shade and shelter area (rest place) any given distance, such as benches and trees as a shade.

5. To provide clear signage for cyclist paths, pedestrian paths, and public transportation information.

6. To design a ramp, guiding block (blind pattern), for disabled users, senior citizens, and children.

The above pedestrian path design recommendations are expected to increase people's motivation to walk. And this can also be used as input for the official government policy text for pedestrian path standards in Jakarta.

Based on the research, it needs further research by assessing the combination of pedestrian satisfaction and safety concerning infrastructure and pedestrian path environments. It aims at the convenience and security of pedestrian way facilities.

\section{Acknowledgement}

I would like to express their sincere thanks to my student:

- Arnott Ferrel (2016-AR 3), who provide the pedestrian path and vehicle road illustration. 
p-issn: 2581-1347 | e-issn: 2580-2607 | Pg. 61 - 72

- Green building course students (2017-AR 4), who collect primary data.

\section{References}

[1]. Asadi-Shekari Z, Moeinaddini M, Shah MZ. A Pedestrian Level of Service Method for Evaluating and Promoting Walking Facilities on Campus Streets. $J$ of Transp Eng 2013;139:181-192

[2]. Badan Pusat Statistik, (Statistic Data Centre), Jakarta Transportation Data of Vehicle; 2018, https://bps.go.id/site/resultTab.

[3]. Daamen W, Hoogendoorn SP. Free Speed Distributions-Based on Empirical Data in Different Traffic Conditions: Pedestrian and Evacuation Dynamics. Waldau N, ed., Berlin: Springer; 2005, p. 1325.

[4]. Fruin JJ. Pedestrian Planning and Design, New York: Metropolitan Association of Urban Designers and Environmental Planner; 1971.

[5]. Governor Regulation, Governor Regulation Number 155 Year 2018 concerning Traffic Restrictions with the Even-Odd System; 2018. (Peraturan Gubernur, (2018), Peraturan Gubernur Nomor 155 Tahun 2018 tentang Pembatasan Lalu Lintas dengan Sistem GanjilGenap.)

[6]. Governor Regulation, Spatial Planning for DKI Jakarta Province in 2010-2030; 2009.

[7]. Pan J. Research on Green Transportation and Transfer System in Urban Area, Proceedings of the 2012 International Conference on Automobile and Traffic Science, Materials, Metallurgy Engineering (MMAT 2012); 2012.

[8]. Lam WHK, Cheung C. Pedestrian speed/flow relationships for walking facilities in Hong Kong. $J$ Transp Eng 2000;126(4):343-349

[9]. Landis $\mathrm{BW}$, et al. Modeling the roadside walking environment: A Pedestrian Level of Service. Transportation Research Board; 2001

[10]. Litman TA. Economic Value of Walkability. J Transp Res Board 2003;1828:3-11

[11]. Litvin SW. Streetscape improvements in an historic tourist city a second visit to King Street, Charleston, South Carolina. Tour Manag 2005;26:42129

[12]. McManus PM. J Tour Stud 1998;19:40-50

[13]. Papadimitriou EA. Patterns of pedestrian attitudes, perceptions and behaviour in Europe, Europe Safety Science 2013;53:114-122.

[14]. Pucher J, Buehler R, Seinen M. Bicycling renaissance in North America? An update and re- appraisal of cycling trends and policies. Transp Res Part A 2011;45 451-475

[15]. Rajat $\mathrm{R}$, Ilango $\mathrm{T}$, $\mathrm{C}$ Satish C. Design Implications of Walking Speed for Pedestrian Facilities. J Transp Eng 2011

[16]. Zainol R, Ahmad F, Nordin NA, Aripin AWM, Evaluation of users' satisfaction on pedestrian facilities using pair-wise comparison approach. IOP Conf. Series: Earth and Environmental Science 2014;18:012175

[17]. Saaty TL. Decision making with the analytic hierarchy process. Int J Serv Sci 2008;1:83-98

[18]. Southworth M. Reclaiming the Walkable City. J Urb Plan Dev Fall 2005.

[19]. Stradling SG, Anable J, Carreno M. Performance, importance and user disgruntlement: A sixstep method for measuring satisfaction with travel modes. Transp Res Part A. 2007

[20]. Vuchic RV. Urban Public Transportation Systems, Transportation Engineering and Planning Vol. I - no 2 Encyclopedia of Life Support Systems (EOLSS) United Nation Educational Scientific and cultural organization; 2011.

[21]. Forsyth, Ann. What is a walkable place? The walkability debatein urban design. Urban Design International 20, no.4: 274-292. 2015 